International Journal of Business Management and Economic Review

Vol. 4, No. 05; 2021

ISSN: 2581-4664

\title{
THE EFFECT OF PERFORMANCE EXPECTANCY, EFFORT EXPECTANCY, FACILITATING CONDITIONS, AND BEHAVIOR ON ADOPTION OF E- GOVERNMENT TRANSFORMATION IN DISTANBUN ACEH OFFICE EMPLOYEES WITH AGE AND WORKING PERIOD AS MODERATION VARIABLES
}

\author{
*Dara Thursina, Said Musnadi and Syafruddin \\ Department of Management, Universitas Syiah Kuala, Indonesia \\ http://doi.org/10.35409/IJBMER.2021.3310
}

\begin{abstract}
The application of e-government in government agencies such as the Aceh Agriculture and Plantation Office (Distanbun Aceh Office) certainly requires the support of information technology infrastructure. The importance of information technology infrastructure in supporting the implementation of e-government is because the application of e-government requires the availability of information technology as an important determinant in supporting the program. The purpose of this study is to see the effect of performance expectancy, effort expectancy, facilitating conditions, and user behavior on the e-government transformation adoption with age and working period as moderating variables at the Distanbun Aceh Office. The population was all employees of the Distanbun Aceh Office, totaling 695 people. Sampling was carried out using proportional stratified random sampling technique to all employees at each Distanbun Aceh Office while the minimum number of samples was determined using the Slovin formula. The results showed that out of 4 direct hypotheses, 3 were accepted and 1 hypothesis was not significant, namely testing the effect of Facilitator Conditions on e-Government transformation adoption. The results of testing the moderation hypothesis of age and working period for the full model proved that there were significant differences between young and old groups, and high and low working periods in responding to managerial initiations related to Performance Expectancy, Effort Expectancy, Facilitating Condition, and User Behavior on the application of E-Government. So these findings imply that in the model of increasing e-government transformation adoption at Distanbun Aceh, Performance Expectancy, Effort Expectancy, and User Behavior are the 3 determining factors, and also the implementation of strengthening these three factors must consider differences in age and working period of employees, so that increasing e-government transformation adoption can be maximized.
\end{abstract}

Keyword: Performance Expectancy, Effort Expectancy, Facilitating Condition, User Behavior, E-Government Transformation Adoption, Age, and Working Period.

\section{INTRODUCTION}

Good governance is an important issue in the management of public administration. In order to improve good governance, the government seeks to implement electronic government (egovernment). E-government initiatives in Indonesia have been introduced through Presidential 


\section{International Journal of Business Management and Economic Review}

Vol. 4, No. 05; 2021

ISSN: 2581-4664

Instruction No. 6/2001 date. 24 April 2001 concerning Telematics (Telecommunications, Media and Informatics) which stated that government officials must use telematics technology to support good governance and accelerate the democratic process.

Information technology infrastructure is intended to be related to point the use of information technology resources (Byrd \& Brown, 2002). The application of e-government in government agencies such as the Aceh Agriculture and Plantation Office (Distanbun Aceh Office), one of the institutions in Indonesia, certainly requires the support of information technology infrastructure. The importance of information technology infrastructure in supporting the implementation of e-government is because the application of e-government requires the availability of information technology as an important determinant in supporting the program. Without good information technology, the implementation of e-government in government agencies may not be carried out as expected.

The phenomenon related to the application of the principles of good governance in this institution was perceived differently by employees. The results of the initial survey using interviews with a number of the employees were not all have a good assessment on the transparency principle in the institution. In addition, the effectiveness and efficiency of activities, which should be one of the important indicators of implementing the principles of good governance, were also deemed not fully manifest in the operational activities of the institution. Furthermore, concerning accountability as an important indicator of the implementation of good governance, employees also perceived it as relatively different. There were still some employees who stated that there was a lack of accountability for activities in the institution (Imari, Lubis, \& Chen, 2017).

\section{LITERATURE REVIEW}

\section{E-Government Transformation Adoption}

E-government is a government effort to get closer to society. Based on the definition of (Layne \& Lee, 2001), e-government is a front line of government plans to support and provide information and service improvements to the public, business people, government workers, other government units, and third sector organizations. The Ministry of Communication and Information said that e-government is an application of internet-based information technology and other digital devices managed by the government for the purpose of conveying information from the government to the public, business partners, employees, business entities, and other institutions online (Azhari, Musnadi, \& Tabrani, 2017).

\section{Performance Expectancy}

Performance expectancy is defined as how high a person/individual belief that the functioning of technological innovation will be able to help him get various profits in his career and job. Individual performance is expected to be in line with organizational performance (Venkatesh, Thong, \& Xu, 2012). Performance expectation is a person's belief that if he uses technology it will improve his performance at work (Venkatesh, Morris, Davis, \& Davis, 2003). Performance expectations can explain that using a system will provide benefits in working. Research shows that the role of this variable is very effective and productive for use by students and lecturers because it can improve learning outcomes. 
International Journal of Business Management and Economic Review

Vol. 4, No. 05; 2021

ISSN: 2581-4664

\section{Effort Expectancy}

(Venkatesh et al., 2012) stated that the simplicity of using technological innovation will be able to foster a person's self-confidence, that the system has used and therefore creates a sense of security and comfort in wearing it. Several indicators stated that innovation is said to be simple in terms of ease of use such as easy to work on, it does not require a lot of manpower and resources to operate (Ojaide \& Agochukwu, 2016). Working with these innovations is not difficult and you will find maximum benefits as a form of effort in a field of work. Individuals will believe that the use of these innovations will give them the advantage that previously existed.

\section{Facilitating Conditions}

The facility condition variable is defined as how much a person believes the facilities and infrastructure that support the system on an organizational and technical infrastructure are available reliably (Goldsmith, 2015). The concept of facility conditions is such as perceptions of behavioral control, which is a reflection of the inner and outer limits of a person's behavior, includes his perception (self-efficacy), the state of the condition of the resource facility, and the existence of facility conditions. Facility condition factors are interpreted as objective variables in the environment where observations agree to make an action easily carried out, including the provision of computer support (Workman, 2014).

\section{User Behavior}

The adoption of an E-Government system in an organization really depends on the readiness of the users within the organization. This is in line with the Technolgy Acceptance Model (TAM) theory, which is an information system theory that models how users accept and use technology (Davis \& Davis, 1989). The actual use of systems is the endpoint where everyone can do with technology, so we have to establish Behavioral Intention, which is the factor that leads people to use technology. Behavioral intention (BI) is influenced by attitude (A) which is the general impression of the technology (Asni, Nasir, Yunus, \& Darsono, 2018). User behavior is determined by the intention or desire of someone to use it. Use behavior can be seen from the extent to which someone is satisfied with using technology, the belief that the technology is easy to use, and will increase their productivity.

\section{Research Paradigm}

The paradigm in this study is illustrated in Figure 1 below. 


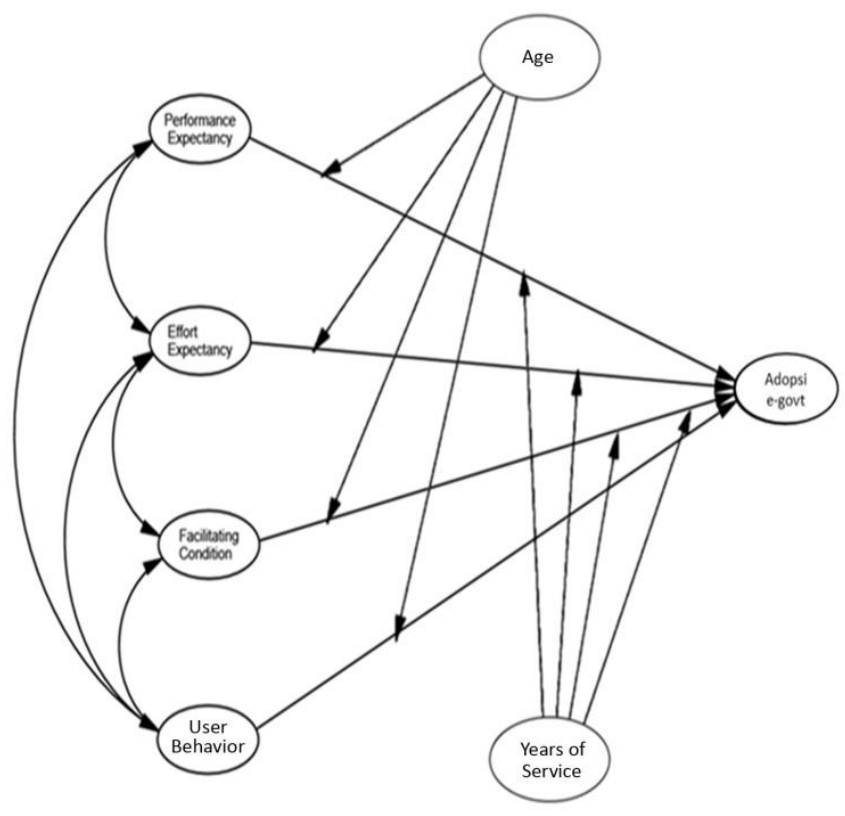

Figure 1. Research Paradigm

\section{Hypothesis}

Based on the phenomena and from the theoretical foundations, several alternative hypotheses can be stated as follows.

H1: Performance expectancy affects the e-government transformation adoption at the Distanbun Aceh Office

$\mathrm{H} 2$ :Effort expectancy affects the e-government transformation adoption at the Distanbun Aceh Office

$\mathrm{H} 3$ :Facilitating conditions affects the e-government transformation adoption at the Distanbun Aceh Office

H4 : User behavior affects the e-government transformation adoption at the Distanbun Aceh Office

H5: Age moderates Performance expectancy affecting the e-government transformation adoption

H6: Age moderates Effort expectancy affecting the e-government transformation adoption

H7: Age moderates Facilitating conditions affecting the e-government transformation adoption

H8: Age moderates the effect of user behavior on the e-government transformation adoption

H9: Working period moderates performance expectancy affecting the e-government transformation adoption

H10: Working period moderates Effort expectancy affecting the e-government transformation adoption

H11: Working period moderates facilitating conditions affecting the e-government transformation adoption

H12: Working period moderates user behavior affecting the e-government transformation adoption 
International Journal of Business Management and Economic Review

Vol. 4, No. 05; 2021

ISSN: 2581-4664

\section{RESEARCH METHOD}

\section{Location and Object}

The location of this research was carried out at the Distanbun Aceh Office. The subjects of this study were all employees at the Distanbun Aceh Office. The variables of this research were the effect of performance expectancy, effort expectancy, facilitating conditions, user behavior, the egovernment transformation adoption, age, and working period.

\section{Sampling}

The population was all 695 Aceh Civil Servants (PNS) of the Distanbun Aceh Office. Sampling was carried out using a proportional stratified random sampling technique for all employees at Distanbun Aceh Office. This study establishes proportional stratified random sampling as a method of sampling the employees who work at the Distanbun Aceh Office. While determining the minimum number of samples used the Slovin formula, (Umar, 2008)

\section{Data analysis method}

Data obtained in the field was processed by using the Structural Equation Modeling technique (SEM). The criteria for acceptance of $\mathrm{Ha}$ are Critical Ratio (CR)> 1.96 and the value of Probability $(\mathrm{P})<0.05$.

\section{RESULT}

\section{Loading Factor in Measurement Model}

Testing the validity of loading factors can be seen in the following figure and table.

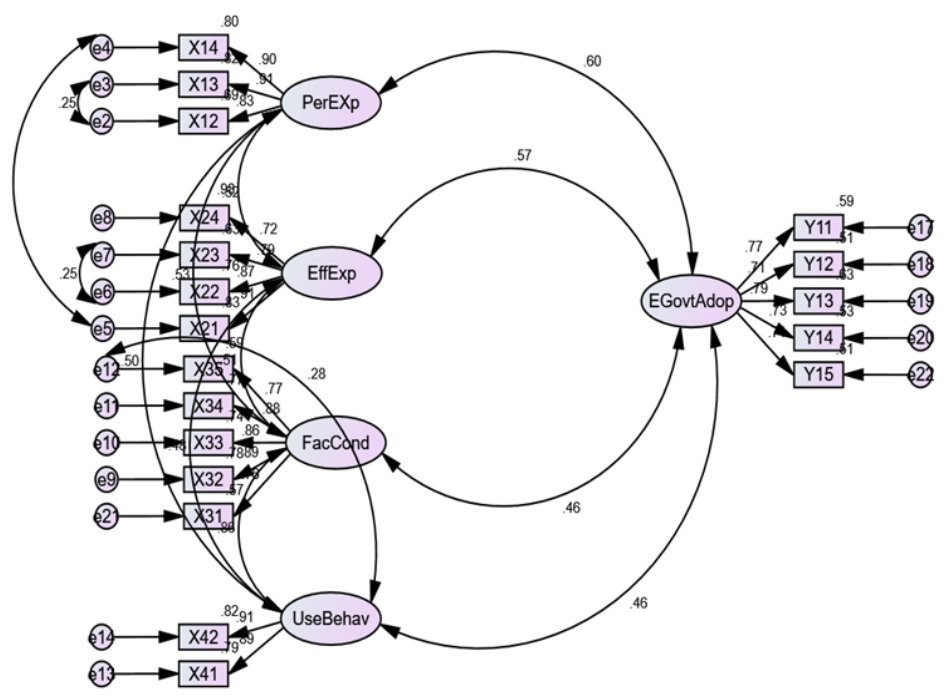

Figure 2. Loading Factor

From the final result above we can see the measurement test result previously has indicated several indicators of the research variables have a loading factor value below 0.5 and 
International Journal of Business Management and Economic Review

Vol. 4, No. 05; 2021

ISSN: 2581-4664

have eliminated from the mode, and the rests have met the requirements for further processing because it has a loading factor value $>0.5$.

Table 1. The goodness of Fit Criteria

\begin{tabular}{|l|l|l|l|}
\hline Size Index Criteria & Cut-off Value & $\begin{array}{l}\text { Analysis } \\
\text { Results }\end{array}$ & $\begin{array}{l}\text { Model } \\
\text { Evaluation }\end{array}$ \\
\hline CMIN / DF & $<2$ & 1,994 & Good \\
\hline RMSEA & $\leq 0.08$ & 0.059 & Good \\
\hline GFI & $\geq 0.90$ & 0.91 & Good \\
\hline AGFI & $\geq 0.90$ & 0876 & Good \\
\hline
\end{tabular}

\section{Structural Model for Direct Hypothesis testing}

The results of the structural testing are shown in the figure below.

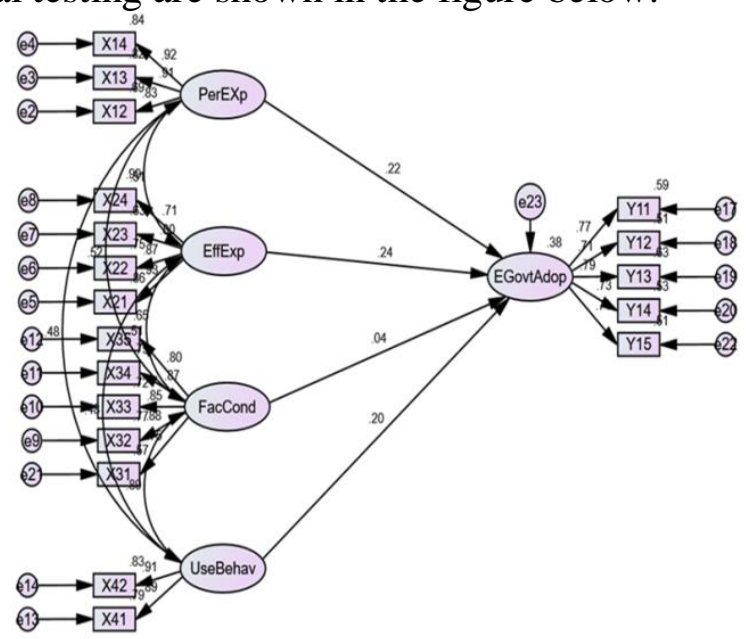

Figure 3. Structural Model for Direct Effect

Based on Figure 2, it can be explained that the influence of each variable is the influence of performance expectancy, effort expectancy, facilitating conditions, and user behavior on the e-government transformation adoption. An overview of all hypothesis testing along with the results can be seen in Table 2 below:

Table 2. Hypothesis Conclusion

\begin{tabular}{|c|l|l|l|l|}
\hline No. & Hypothesis & $\begin{array}{l}\text { CR Cut } \\
\text { off }>\mathbf{1 . 9 6}\end{array}$ & $\begin{array}{l}\text { P-Value } \\
\text { Cut } \\
<\mathbf{0 . 0 5}\end{array}$ & $\begin{array}{l}\text { Informati } \\
\text { on }\end{array}$ \\
\hline H1 & $\begin{array}{l}\text { Performance Expectancy affects the e- } \\
\text { government transformation adoption }\end{array}$ & 6.313 & $* * * *$ & .088 \\
\hline H2 & $\begin{array}{l}\text { Effort Expectancy affects e-Government } \\
\text { transformation }\end{array}$ & 7.667 & $* * * *$ & .515 \\
\hline
\end{tabular}


Vol. 4, No. 05; 2021

ISSN: 2581-4664

\begin{tabular}{|c|c|c|c|c|}
\hline No. & Hypothesis & $\begin{array}{l}\text { CR Cut } \\
\text { off }>1.96\end{array}$ & \begin{tabular}{|l|} 
P-Value \\
Cut \\
$<0.05$
\end{tabular} & $\begin{array}{l}\text { Informati } \\
\text { on }\end{array}$ \\
\hline $\mathrm{H} 3$ & $\begin{array}{l}\text { Facilitating Conditions affects the e- } \\
\text { government transformation adoption }\end{array}$ & 0.234 & 0.815 & .442 \\
\hline $\mathrm{H} 4$ & $\begin{array}{l}\text { User Behavior affects the e-government } \\
\text { transformation adoption }\end{array}$ & 2.066 & 0.043 & .036 \\
\hline
\end{tabular}

It can be seen from the 4 direct hypotheses that there is 1 (one) insignificant hypothesis, namely testing the effect of Facilitator Conditions on the e-government transformation adoption because it has a CR value of 0.234 and a $\mathrm{P}$ value of 0.815 which does not meet the minimum requirements of the accepted hypothesis. In other words, other independent variables, namely performance expectancy, effort expectancy, and user behavior towards the e-government transformation adoption can be well accepted as long as the independent variables can be improved by the leadership or management at the Distanbun Aceh Office.

\section{Moderation Hypothesis Testing}

Age Variable

Testing the moderation hypothesis to prove whether there is a difference between the Young and Old Age groups in responding to initiatives carried out by management related to Performance Expectancy, Effort Expectancy, Facilitating Conditions, and User Behavior towards the implementation of e-Government policies in this office. The results are shown in Table 3 below.

Table 3. Conclusion of the Age As Moderation

\begin{tabular}{|l|l|l|l|l|}
\hline $\begin{array}{l}\text { No } \\
\cdot\end{array}$ & Moderation Hypothesis & $\begin{array}{l}\text { Beta } \\
\text { (Young } \\
\text { Age) }\end{array}$ & $\begin{array}{l}\text { Beta } \\
\text { (Old } \\
\text { Age) }\end{array}$ & Difference \\
\hline 1 & $\begin{array}{l}\text { Performance Expectancy affects the e- } \\
\text { government transformation adoption }\end{array}$ & 0.236 & 0.122 & $\mathbf{0 . 1 1 4}$ \\
\hline 2 & $\begin{array}{l}\text { Effort Expectancy affects the e-government } \\
\text { transformation adoption }\end{array}$ & $\mathbf{0 . 2 5 6}$ & 0.143 & 0.113 \\
\hline 3 & $\begin{array}{l}\text { Facilitating Conditions affects the e- } \\
\text { government transformation adoption }\end{array}$ & 0.065 & 0.007 & 0.058 \\
\hline 4 & $\begin{array}{l}\text { User Behavior affects the e-government } \\
\text { transformation adoption }\end{array}$ & 0.177 & $\mathbf{0 . 2 0 2}$ & 0.025 \\
\hline & Total & $\mathbf{0 . 7 3 4}$ & 0.474 & $\mathbf{0 . 3 1 0}$ \\
\hline
\end{tabular}

From Table 4 above, in general, it can be seen that the Young Age group is more responsive than the Old Age group because it has a higher accumulation of beta numbers, namely 0.734 compared to 0.474 in the Old Age group. If we look at the path that has the beta number with the highest difference in these two groups of respondents, the path of performance expectations for e-Government adoption which has the highest difference in beta numbers between these two groups is 0.114 . 
International Journal of Business Management and Economic Review

Vol. 4, No. 05; 2021

ISSN: 2581-4664

\section{Working Period Moderation Hypothesis Testing}

Moderation hypothesis testing to prove whether there is a difference between groups with a longer and less working period. In this case, the working period is divided into two, namely those who have a work period of more than 10 years and under 10 years. How do these two groups respond to initiatives undertaken by management related to Performance Expectancy, Effort Expectancy, Facilitating Conditions, and User Behavior towards the implementation of eGovernment policies in this office?

The results are as shown in Table 4 below:

Table 4. Hypothesis Conclusion Of the Working Period As Moderation

\begin{tabular}{|l|l|l|l|l|}
\hline $\begin{array}{l}\text { No } \\
\cdot\end{array}$ & Moderation Hypothesis (Low & $\begin{array}{l}\text { Beta (High } \\
\text { Working } \\
\text { Period) }\end{array}$ & Difference \\
\hline 1 & $\begin{array}{l}\text { Performance Expectancy affects the e- } \\
\text { Working } \\
\text { Period) } \\
\text { government transformation adoption }\end{array}$ & 0.259 & 0.165 & 0.094 \\
\hline 2 & $\begin{array}{l}\text { Effort Expectancy affects the e- } \\
\text { government transformation adoption }\end{array}$ & 0.290 & 0.174 & 0.116 \\
\hline 3 & $\begin{array}{l}\text { Facilitating Conditions affects the e- } \\
\text { government transformation adoption }\end{array}$ & 0.079 & 0.179 & 0.100 \\
\hline 4 & $\begin{array}{l}\text { User Behavior affects the e-government } \\
\text { transformation adoption }\end{array}$ & 0.242 & 0.161 & 0.081 \\
\hline & \begin{tabular}{l} 
Total \\
\hline
\end{tabular} & 0870 & 0.679 & 0.191 \\
\hline
\end{tabular}

From Table 4 above, it is generally seen that the group with the high period is more responsive than the group with a low period because it has a higher accumulated beta number, namely 0.870 compared to 0.679 in the group with the low period.

If you look at the path that has the beta number with the highest difference in the two groups of respondents, the Effort Expectancy path to e-Government adoption which has the highest difference in beta numbers between these two groups is 0.116 .

\section{CONCLUSION}

From the testing, we can conclude the analysis result as follows.

1. In the confirmatory analysis test, there are three indicators that do not meet the requirements so that they must be eliminated from this research model.

2. In testing the goodness of fit to assess the feasibility of the model, it turns out that there are criteria for the fit test model that do not meet the criteria, namely CMIN / DF. Because the $\mathrm{CMIN}$ / DF value does not meet the fit requirements, it is necessary to re-verify the model to obtain the model's eligibility as required. In addition, it has also been conducted to assess the feasibility of the model using RMSEA, GFI, IFI and TLI.

3. In direct hypothesis testing, one of the hypotheses tested, namely the effect of Facilitating Condition on the e-government transformation adoption, shows that the CR value and the probability do not meet the requirements. Thus it can be stated that the effect of Facilitating 
Condition on the e-government transformation adoption is not significant. The coefficient value generated in this hypothesis test is also relatively small so that it is unable to encourage the e-government transformation adoption in the research subject.

4. In the gender moderation test, for the full model, there is a significant difference between male and female groups in responding to managerial initiations related to Performance Expectancy, Effort Expectancy, Facilitating Condition, and User Behavior towards the egovernment transformation adoption. However, in partial moderation testing, only the effect of Performance Expectancy on the e-government transformation adoption is accepted, while the other three partial results are rejected.

5. In the working period moderation test, for the full model, there is a significant difference between the working period group $>10$ years compared to the $<10$ years working period group in responding to managerial initiatives related to Performance Expectancy, Effort Expectancy, Facilitating Condition and User Behavior towards the e-government transformation adoption. However, none of the partial moderation tests were accepted, so it can be concluded that in the path by path test there was no significant difference between the working tenure group $>10$ years compared to the $<10$ years working period group in responding to managerial initiations related to Performance Expectancy, Effort Expectancy, Facilitating Condition and User Behavior for the e-government transformation adoption.

6. The Government of Aceh, in which the Distanbun Aceh Office is included, has realized the importance of adopting this e-government to improve public services that can be accessed anywhere and anytime which is realized through their information system (SIAT). This initiation illustrates the effort expectancy that has been carried out both at the provincial government level in general, as well as at the technical level in the districts.

Several suggestions can be provided from the analysis.

1. Facilitating Condition does not show its contribution at all to the model, because its effect is not significant. However, the other 3 variables show a positive and significant influence on the application of E-Government. So that in this context the authors suggest ignoring this Facilitating Condition variable in improving the quality of the implications of implementing e-government in this office.

2. Because there are three independent variables that are considered to fully contribute, namely Performance Expectancy on the e-government transformation adoption, Effect of Effort Expectancy on the e-government transformation adoption, and Effect of User Behavior on the e-government transformation adoption, Of the three variables, Effort Expectancy, and Performance Expectancy are variables that dominance in determining the success of implementing e-government. Therefore, the authors suggest that in an effort to support the successful implementation of e-government, the effort expectancy variable is the most priority variable in improving its performance, because its contribution to the successful adoption of e-government is highly expected.

3. Future researchers can develop this tested model by adding variables such as employee motivation and employee learning ability to support the adoption of e-government transformation.

\section{REFERENCES}

Asni, K., Nasir, Yunus, M., \& Darsono, N. (2018). Analysis on Internet Banking Services in 


\section{International Journal of Business Management and Economic Review}

Vol. 4, No. 05; 2021

ISSN: 2581-4664

Indonesia: Impact of Customer Value to Converting Intention. Proceedings of the 1st Aceh Global Conference (AGC 2018), 498-505. https://doi.org/https://doi.org/10.2991/agc18.2019 .73

Azhari, Musnadi, S., \& Tabrani, M. (2017). Pengaruh Manajemen Pengetahuan, Gaya Kepemimpinan Dan Insentif Terhadap Kinerja Pegawai Serta Implikasinya Terhadap Kinerja Organisasi Pada Kantor Pelayanan Pajak Pratama Banda Aceh. Jurnal Manajemen Dan Inovasi, 8(2), 1-14.

Byrd, J., \& Brown, P. L. (2002). The Innovation Equation: Building Creativity and Risk-Taking in Your Organization. New Jersey: Wiley.

Davis, F. D., \& Davis, F. (1989). Perceived Usefulness, Perceived Ease of Use, and User Acceptance of Information Technology. MIS Quarterly, 13(3), 319-339. https://doi.org/10.2307/249008

Goldsmith, E. B. (2015). Social Influence History and Theories. In International Series on Consumer Science (pp. 23-39). https://doi.org/https://doi.org/10.1007

Imari, S., Lubis, P. H., \& Chen, S. (2017). Pengaruh Orientasi Belanja Kepercayaan Online dan Pengalaman Pembelian Sebelumnya Terhadap Niat Pembelian Konsumen Secara Online dengan Perbedaan Gender Sebagai Variabel Pemoderasi. Jurnal Magister Manajemen2, $1(1)$.

Layne, K., \& Lee, J. (2001). Developing fully functional E-government: A four stage model. Government Information Quarterly, 18(2), 122-136. https://doi.org/https://doi.org/10.1016/S0740-624X(01)00066-1

Ojaide, F., \& Agochukwu, O. (2016). The Effect of Effort Expectancy on Computer-Assisted Audit TechniquesUsage by External Auditors in Nigeria. IJSMR, 3(1), 193-204.

Umar, H. (2008). Metode Penelitian untuk Skripsi dan Tesis (Ed. Kedua). Depok: RajaGrafindo Persada.

Venkatesh, V., Morris, M. G., Davis, G. B., \& Davis, F. D. (2003). User Acceptance of Information Technology: Toward a Unified View. MIS Quarterly, 27(3), 425-478. https://doi.org/https://doi.org/10.2307/30036540

Venkatesh, V., Thong, J. Y. L., \& Xu, X. (2012). Consumer Acceptance and Use of Information Technology: Extending the Unified Theory of Acceptance and Use of Technology. MIS Quarterly, 36(1), 157-178. https://doi.org/10.2307/41410412

Workman, M. D. (2014). New media and the changing face of information technology use: The importance of task pursuit, social influence, and experience. Computers in Human Behavior, 31(1), 111-117. https://doi.org/10.1016/j.chb.2013.10.008 